\title{
Molecular docking of various bioactive compounds from essential oil of Trachyaspermum ammi against the fungal enzyme Candidapepsin-1
}

\author{
Abhishek Biswal R., Venkataraghavan R., Vivek Pazhamalai*, Ivo Romauld S. \\ Department of Bio-Engineering, School of Engineering, Vels Institute of Science, Technology, and Advanced Studies (VISTAS), Chennai, India.
}

\begin{tabular}{l}
\hline ARTICLE INFO \\
\hline Received on: 30/12/2018 \\
Accepted on: 02/04/2019 \\
Available online: 08/05/2019 \\
\\
\hline Key words: \\
Trachyaspermum ammi, \\
Candidapepsin-1, Lipinski, \\
molecular simulation, drug \\
targets.
\end{tabular}

\begin{abstract}
The bioactive compounds from essential oil of Trachyaspermum ammi using gas chromatography-mass spectrometry and their inhibition potential against the enzyme Candidapepsin-1 were studied. The research work focuses on the molecular simulation of bioactive compounds against the enzyme that acts as a potential drug target and support the drug discovery process. Candidapepsin-1 has been reported to be the cause for biofilm formation, superficial skin infections, and oral infections. Fifteen active compounds and their interactions with Candidapepsin-1 were studied in this research work. The compounds satisfied Lipinski's rule of five in order to be used as an oral drug. ADMET properties of the compounds used to determine pharmacodynamic and pharmacokinetic properties which were reported in the study. The compounds were docked against the enzyme with the help of AutoDock 4.2.6 software. Ligustilide has the lowest free binding energy of $-5.75 \mathrm{kcal} / \mathrm{mol}$ against the Candidapepsin- 1 with three hydrogen bond interactions at Ile 223, Tyr 225, and Thr 222 at the active site of the enzyme followed by cedrane with -5.20 $\mathrm{kcal} / \mathrm{mol}$. The hydrogen bond interactions, Vander Waals interactions, and two-dimensional and three-dimensional interactions were studied.
\end{abstract}

\section{INTRODUCTION}

Trachyaspermum ammi often known as Ajwain or carom seeds or bishop's weed is a plant seed that are widespread across diverse areas of India and are cultivated predominantly in north-western states of India like Gujarat and Rajasthan, Madhya Pradesh and in other countries like Afghanistan, Bangladesh, Egypt Iran, and Iraq. Trachyaspermum ammi belongs to the family of Apiaceae, dicot and possess high medicinal properties. Trachyaspermum ammi is used by the people traditionally as it possesses several properties to cure diverse liver, lungs, and stomach disorders. Trachyaspermum ammi is commonly used as an herbal medicine by the people. The seed also possesses carminative and antispasmodic properties which make it an effective remedy

"Corresponding Author

Vivek Pazhamalai, Department of Bio-Engineering, School of Engineering, Vels Institute of Science, Technology, and Advanced Studies (VISTAS), Chennai, India.E-mail:viveksncet2011@gmail.com for various disorders, such as indigestion, abdominal pain, piles, amenorrhea, bronchial inflammation, asthma, hepatoprotective agent, and chronic diarrhea (Bairwa et al., 2012). Research has shown the significant antibacterial properties of T. ammi against a wide variety of bacteria, such as Staphylococcus aureus, Escherichia coli, Enterococcus faecalis, Shigella flexneri, and Salmonella typhi (Kaur and Arora, 2009). Multiple drug resistant fungal strains, such as Candida albicans, Candida krusei, Candida tropicalis, and Candida glabrata, were also inhibited by T. ammi (Khan et al., 2010). Volatile oils of T. ammi has the potential to for antifungal properties against $C$. albicans and Aspergillus species (Ishwar and Singh, 2000). The plant and its seeds contain several phytochemicals and essential oils, such as thymol, g-Terpinene, isobornylisobutyrate, o-Cymene, p-Cymene, a-Pinene, silphine, verbenene, ionone myrcene, thymyl acetate, etc. (Dhaiwal et al., 2017). Thymol is the major constituent of T. ammi seeds. Trachyaspermum ammi contains $50 \%$ of thymol. Thymol is an essential oil obtained from the seeds of T. ammi and finds applications in toothpaste and perfume industries (Joshi, 2000). 


\section{Phytochemical analysis}

Trachyaspermum ammi contains diverse phytochemicals. Carbohydrates make the predominant principal composition (38.6\%), fats (18.1\%), proteins $(15.4 \%)$, flavone and saponins (7\%). Ajwain also contains trace elements of calcium, nicotinic acid, and iron (Pruthi and Jiwan Singh, 1998). Thymol $(36 \%-60 \%)$ is the major proportion of ajwain fruits essential oils (Ishikawa et al., 2001). Other principal oils in T. ammi are carvone (46\%), dillapiole, and limonene. Non-thymol (thymene) fractions are $\gamma$-terpenine, dipentene, $\alpha$-terpenine, $\alpha$-pinene, $\beta$-pinene, para-cymene, $\alpha-3$-carene, and carvacrol. Ethanolic extracts of ajwain fruits yields hydroscopic saponins. Characteristic yellow colored flavone isolated from ajwain fruits possesses 6-O- $\beta$ glucopyranosyloxythymol, oleoresin, and volatile oils (Garg and Kumar, 1998).

Pharmacological and medicinal activities of Trachyaspermum ammi (ajwain)

Trachyaspermum ammi (Ajwain) has a characteristic aromatic and pungent smell. Often, the seeds are used as spices in recipes, perfume industry, and food preservatives. In Ayurveda, ajwain is used to heal stomach- and liver-related disorders. A fraction of crushed fruits of ajwain are used to cure colonic pains. Dry and hot fomentations of fruit extracts are applied externally onto the chest to relieve asthma- and lung-related disorders. Ajwain seeds have shown potential to have anti-inflammatory property, antifungal (Saeidnia et al., 2005), antibacterial, antifilarial (Mathew et al., 2008), digestive stimulant, antiplasmodic, broncho-diliating, galactogogic (Kaur, 1998), detoxification of toxins G1 (AFG 1) (Velazhahan et al., 2010), diuretic (Ahsan et al., 1990), antihelminthic, hypolipidemic (Kumari and Prameela, 1992), and gastroprotective properties. Trachyaspermum ammi has shown potential to cure carbon tetrachloride- and paracetamolinduced liver damage in male albino rats (Gilani et al., 2005). Trachyaspermum ammi also has proven records that to cure hypertension and colonic diarrhea (Gilani et al., 2005).

\section{Candidapepsin-1 enzyme structure}

The Candidapepsin-1 (EC: 3.4.23.24) is an apoenzyme and belongs to the class of Secreted aspartic proteinase (Sap) family (Sanglard et al., 1997; Smolenski et al., 1997). The gene responsible for this enzyme is SAP1 and is located on the chromosome 6 of the organism. The Candidapepsin-1 is a proteolytic virulent enzyme from the endophytic polymorphic fungal species $C$ albicans and is responsible for superficial Candida infections like oral and skin infections in immunocompromised individuals (Correia et al., 2010; Meenambiga et al., 2018; Staib et al., 2000). The enzyme invades and adheres to the host tissue by digesting the host cell membrane and small molecules to acquire nutrition. The enzyme digests the cell host cell membrane to inhibit the attack from the host immune system (Naglik et al., 2003). The enzyme attacks the oxygen carrier molecule hemoglobin through its proteolytic activity and releases various antimicrobial hemocidins to combat against various microbes of the same niche (Schaller et al., 2001). The enzyme is very stable and active at pH 5.0 (Aoki et al., 2011). This enzyme is similar in structure and function with its isoenzyme Candidapepsin-5. There are 10 subclasses of acidic hydrolases in the Sap family from Candidapepsin-1 to
10. The structural investigation discloses the highly conserved overall secondary structure of Candidapepsin-1 enzyme (Borelli et al., 2008). However, Candidapepsin-1, Candidapepsin-2, and Candidapepsin-3 differ from Candidapepsin-5 in two aspects, namely, the net overall electrostatic charge and structural conformation of its entrance toward the active site of the enzyme (Borelli et al., 2008). The active site of the enzyme holds a net negative electrostatic charge due to the presence of basic amino acids. The enzyme contains two chains A and B with 391 amino acid residues and molecular weight of $41.6 \mathrm{KDa}$. The active site is located between the positions at Asp82 and Asp267 of the enzyme. The entry toward the active site of the enzyme is wider. Figure 1 denotes the three-dimensional structure of the Candidapepsin-1 enzyme. The most predominant inhibitor of the enzyme is Pepstatin A. Hence, molecular docking of the enzyme with bioactive plant secondary metabolites supports the existing drug development process as molecular chemical interactions can be comprehensively studied.

\section{MATERIALS AND METHODS}

Bioactive compounds obtained from gas chromatographymass spectrometry (GC-MS) analysis of Trachyaspermum ammi essential oils

The bioactive compounds from essential oils of T. ammi were obtained from the conventional hydrodistillation process using Dean-Stark apparatus (Dhaiwal et al., 2017; Javed et al., 2012). The essential oils were analyzed using GC-MS (Dhaiwal et al., 2017).

The information about the bioactive compounds, such as IUPAC name, structure, and chemical formula, were retrieved from PubChem database (Table 1). The bioactive compounds mentioned in Table 1 were used for molecular docking against the enzyme Candidapepsin-1. Lipinski properties and ADMET properties of the compounds were studied.

\section{Enzyme target preparation}

The enzyme Candidapepsin-1 (PDB Id: 2qzw) was used as the drug target in this research work with resolution $2.05 \AA$ and the method of incorporation was done using X-ray diffraction. The

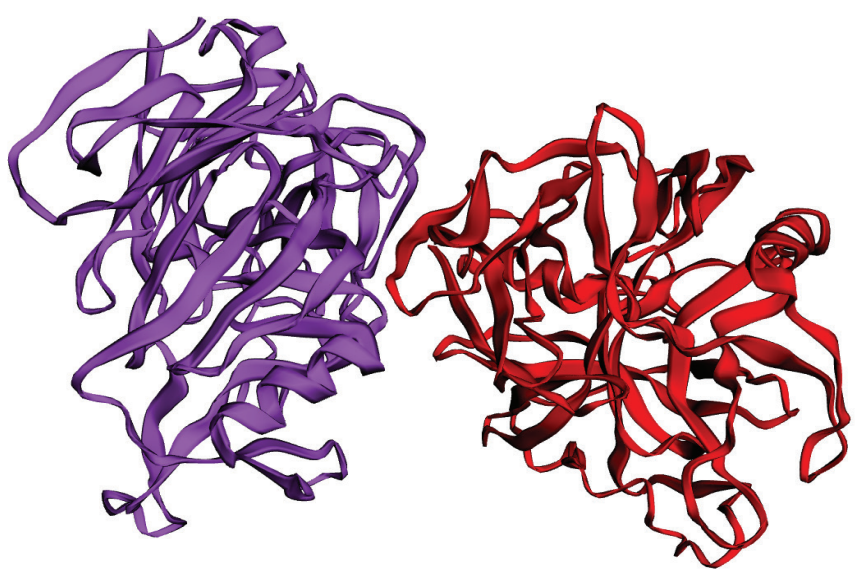

Figure 1. Three-dimensional structure of Candidapepsin-1 (PDB Id: 2qzw) with chain $\mathrm{A}$ and $\mathrm{B}$. 
Table 1. Bioactive compounds from essential oil of T. ammi analyzed through GC-MS analysis reported by Dhaiwal et al. (2017).

\begin{tabular}{|c|c|c|c|c|}
\hline S. no & Compound & IUPAC name & Structure & Chemical formula \\
\hline 1 & Cedrane & $\begin{array}{l}(1 \mathrm{~S}, 2 \mathrm{R}, 5 \mathrm{~S}, 7 \mathrm{~S}, 8 \mathrm{R})-2,6,6,8- \\
\text { tetramethyltricyclo }[5.3 .1 .0(1,5)] \\
\text { undecane }\end{array}$ & & $\mathrm{C}_{15} \mathrm{H}_{26}$ \\
\hline 2 & Cineole & 1,8-Epoxy-p-menthane & & $\mathrm{C}_{10} \mathrm{H}_{18} \mathrm{O}$ \\
\hline 3 & m-Cymene & 1-methyl-3-prop-1-en-2-yl benzene & & $\mathrm{C}_{10} \mathrm{H}_{14}$ \\
\hline 4 & Davanol & $\begin{array}{l}\text { 2-[(2S,5R)-5-ethenyl-5-methyloxolan-2- } \\
\text { yl]-6-methylhept-5-en-3-ol }\end{array}$ & & $\mathrm{C}_{15} \mathrm{H}_{26} \mathrm{O}_{2}$ \\
\hline 5 & Dillapiole & $\begin{array}{l}\text { 4,5-dimethoxy-6-prop-2-enyl-1, } \\
\text { 3-benzodioxole }\end{array}$ & & $\mathrm{C}_{12} \mathrm{H}_{14} \mathrm{O}_{4}$ \\
\hline 6 & Foeniculin & $\begin{array}{l}\text { 1-(3-methylbut-2-enoxy)-4-[(E)-prop-1- } \\
\text { enyl] benzene }\end{array}$ & & $\mathrm{C}_{14} \mathrm{H}_{18} \mathrm{O}$ \\
\hline 7 & Ligustilide & $\begin{array}{l}\text { (3Z)-3-Butylidene-4,5-dihydro-2- } \\
\text { benzofuran-1-one }\end{array}$ & & $\mathrm{C}_{12} \mathrm{H}_{14} \mathrm{O}_{2}$ \\
\hline 8 & Methyl palmitate & Methyl hexadecanoate & & $\mathrm{C}_{17} \mathrm{H}_{34} \mathrm{O}_{2}$ \\
\hline 9 & o-Cymene & 1-methyl-2-propan-2-ylbenzene & & $\mathrm{C}_{10} \mathrm{H}_{14}$ \\
\hline 10 & p-Cymene & 1-methyl-4-propan-2-ylbenzene & & $\mathrm{C}_{10} \mathrm{H}_{14}$ \\
\hline 11 & Phellandrene & $\begin{array}{l}\text { 2-methyl-5-propan-2-ylcyclohexa-1, } \\
\text { 3-diene }\end{array}$ & & $\mathrm{C}_{10} \mathrm{H}_{16}$ \\
\hline 12 & Tetradecanal & Tetradecanal & & $\mathrm{C}_{148} \mathrm{H}_{28} \mathrm{O}$ \\
\hline 13 & Thujanol & $\begin{array}{l}\text { 4-methyl-1-propan-2-ylbicyclo [3.1.0] } \\
\text { hexan-3-ol }\end{array}$ & & $\mathrm{C}_{10} \mathrm{H}_{18} \mathrm{O}$ \\
\hline 14 & Thymol & 5-methyl-2-propan-2-ylphenol & & $\mathrm{C}_{10} \mathrm{H}_{14} \mathrm{O}$ \\
\hline 15 & Totarol & $\begin{array}{l}\text { (4bS,8aS)-4b,8,8-trimethyl-1-propan-2- } \\
\text { yl-5,6,7,8a,9,10-hexahydrophenanthren- } \\
\text { 2-ol }\end{array}$ & & $\mathrm{C}_{20} \mathrm{H}_{30} \mathrm{O}$ \\
\hline
\end{tabular}


protein was retrieved from the Protein Data Bank database. The protein consists of two chains, namely, A and B. One of the protein chains (chain A) was used this study. This was done to improve the accuracy of ligand binding (Sasikala and Meena, 2016). The interfering crystallographic water molecules were also removed from the protein for effective ligand binding (Meenambiga et al., 2018).

\section{ADMET properties of bioactive compounds from essential oil}

Prediction of absorption, distribution, metabolism, and excretion properties of the compounds were done using the freely available SwissADME software package (Kramer et al., 2017). This was performed to enhance the success of drug discovery and development process.

\section{Molecular docking studies using the AutoDock 4.2.6 software}

Molecular docking was performed using the 15 bioactive compounds depicted in the Table 1. The bioactive compounds were docked against the Candidapepsin-1 enzyme using the comprehensive bioinformatics tool AutoDock 4.2.6 software. The AutoDock 4.2.6 is relied on the principle of Lamarckian genetic algorithm and is the most reliable automated tool used by the researchers to understand the protein-ligand interactions and protein-protein interactions (Meenambiga et al., 2015). The ligand-protein structure-based drug designing was performed using this software. AutoDock 4.2.6 is dependent on two techniques, namely, the Rapid-grid based estimation and systematic search of torsional freedom for the ligand-protein molecular docking (Meenambiga et al., 2015).

\section{Grid parameters}

Default grid size of $20 \AA$ was set. Total grid points per map were 64,000 . Grid spacing was $0.375 \AA$ (default). The center grid box sizes were $x$ center: $-16.302, y$ center: -23.34 , and -16.245 , respectively.

\section{Discovery studio 3.1- visualizer}

Discovery studio 3.1 is a visualizer programmed and developed by the Accelrys. This software is free of cost, provides comprehensive information, and is the most often used by the scientific community to view the ligand-receptor interactions. The software provides us with the necessary information about the interactions of small and large molecules taking part in the interaction. The software deals with various aspects of molecular docking, such as macromolecule engineering, ligand-receptor interactions, pharmacophore modeling, antibody modeling \& optimization simulations, macromolecule design, and proteinprotein interactions (Almagro et al., 2011; Luu et al., 2011; Sutter et al., 2011). The two-dimensional and three-dimensional interactions images displayed in this study were developed through this software.

\section{RESULTS AND DISCUSSION}

The following are the bioactive compounds obtained from the GC-MS analysis of essential oil from the seeds of Trachyaspermum ammi: (1) cedrane, (2) cineole, (3) m-cymene, (4) davanol, (5) dillapiole, (6) foeniculin, (7) ligustilide, (8) methyl palmitate, (9) o-cymene, (10) p-cymene, (11) phellandrene, (12) tetradecanal, (13) thujanol, (14) thymol, and (15) totarol. These bioactive compounds were reported by Dhaiwal et al. (2017). Although the bioactive compounds were found to be an effective antioxidant, there were no reports available for the potential of $T$. ammi against the virulence of fungal enzyme, namely, Candidapepsin-1.

Molecular docking of ligands against the active site of the enzyme will elucidate the interactions between them. This will pave way for discovery of novel phytomedicines in the field of drug discovery and development.

The compounds from the GC-MS analysis satisfied the Lipinski's rule of five. This rule comprises of five sub rules, namely, (1) molecular weight $(<500)$, (2) $\log \mathrm{P}(<+5.6)$, (3) Number of hydrogen donors $(<5),(4)$ Number of hydrogen

Table 2. Lipinski properties of bioactive compounds from essential oil of T. ammi.

\begin{tabular}{|c|c|c|c|c|c|c|}
\hline S. no & Compound name & $\begin{array}{c}\text { Molecular weight } \\
\text { (<500 Da) }\end{array}$ & $\log P(<5.6)$ & H-bond donor $(<5)$ & $\begin{array}{c}\text { H-bond acceptor } \\
(<10)\end{array}$ & $\begin{array}{c}\text { Molar refractivity } \\
\quad(40-130)\end{array}$ \\
\hline 1 & Cedrane & 206 & 4.49 & 0 & 0 & 64.60 \\
\hline 2 & Cineole & 154 & 2.74 & 0 & 1 & 45.52 \\
\hline 3 & m-Cymene & 132 & 3.02 & 0 & 0 & 45.88 \\
\hline 4 & Davanol & 238 & 3.46 & 1 & 2 & 71.92 \\
\hline 5 & Dillapiole & 222 & 2.16 & 0 & 4 & 59.56 \\
\hline 6 & Foeniculin & 202 & 4.06 & 0 & 1 & 66.07 \\
\hline 7 & Ligustillide & 190 & 2.87 & 0 & 2 & 54.48 \\
\hline 8 & Methyl palmitate & 270 & 5.60 & 0 & 2 & 82.32 \\
\hline 9 & o-Cymene & 134 & 3.11 & 0 & 0 & 45.26 \\
\hline 10 & p-Cymene & 134 & 3.11 & 0 & 0 & 45.26 \\
\hline 11 & Phellandrene & 136 & 3.16 & 0 & 0 & 45.84 \\
\hline 12 & Tetradecanal & 212 & 4.88 & 0 & 1 & 67.14 \\
\hline 13 & Thujanol & 154 & 2.04 & 1 & 1 & 45.16 \\
\hline 14 & Thymol & 150 & 2.82 & 1 & 1 & 46.93 \\
\hline 15 & Totarol & 286 & 5.54 & 1 & 1 & 88.99 \\
\hline
\end{tabular}


acceptors $(<10)$, and (5) Molar refractivity (40-130). The Lipinski's rule of five is utilized to appraise the drug-likeliness of a compound; in other words, it is very essential criteria for a compound to satisfy this rule in order to be administered orally. The Lipinski's rule of five is also used to assess the durability of a drug molecule (Benet et al., 2016). Hence, this is rule is essential for a bioactive compound to be considered an oral drug (Lipinski et al., 2012). Table 2 represents the detailed information about the bioactive compounds with their respective properties.

The in silico analysis through molecular docking revealed the importance of structure-based drug designing strategy toward the development for novel drugs against the inhibition of potential drug target. The virulent enzyme responsible for superficial skin infections like candidiasis and biofilm formation is Candidapepsin-1 (Korting et al., 1998). The enzyme's active site was docked with several bioactive compounds from T. ammi. The binding energy for each bioactive compound against the Candidapepsin-1 enzyme, interaction of hydrogen bonds, Vander Waals interactions, and essential details were listed in Table 3. Ligustilide has the lowest binding energy of $-5.75 \mathrm{kcal} / \mathrm{mol}$ and has three hydrogen bond interactions with amino acids Ile 223, Tyr 225, and Thr 222 at the active site. Lower the binding energy, greater is the binding efficiency. Greater the hydrogen bonds between the enzyme and ligand determines the strength of binding (Kortemme et al., 2003). The two-dimensional and three-

Table 3. Molecular docking result analysis of bioactive compounds from essential oil of T. ammi against Candidapersin-1 (PDB Id: 2qzw) enzyme.

\begin{tabular}{|c|c|c|c|c|c|c|}
\hline S. no & Compound name & $\begin{array}{l}\text { Binding Energy } \\
\text { Kcal } / \mathrm{mol}\end{array}$ & $\begin{array}{l}\text { No of Vander Waal's } \\
\text { interaction }\end{array}$ & $\begin{array}{l}\text { No. of hydrogen } \\
\text { bonds }\end{array}$ & $\begin{array}{l}\text { Hydrogen bond } \\
\text { interaction }\end{array}$ & $\begin{array}{l}\text { Total polar and non-polar } \\
\text { bonding }\end{array}$ \\
\hline 1. & Cedrane & -5.20 & $\begin{array}{l}\text { GLY } 220 \text {, ASP } 86, \text { THR 221, GLY } \\
85 \text {, ASP 218, SER 35, GLY 34, } \\
\text { LEU } 216 \text {, ILE 223, ASP 32, ILU } \\
\text { 123, ILE } 30, \text { TYR } 84 .\end{array}$ & 0 & 0 & $\begin{array}{l}\text { GLY 220, ASP 86, THR 221, GLY } \\
85 \text {, ASP 218, SER 35, GLY 34, } \\
\text { LEU 216, ILE 223, ASP 32, ILU } \\
\text { 123, ILE } 30 \text {, TYR } 84 .\end{array}$ \\
\hline 2. & Cineole & -4.20 & $\begin{array}{l}\text { ILE } 123 \text {, ILE } 30 \text {, ASP } 86 \text {, SER } 35 \text {, } \\
\text { TYR } 84 \text {, GLY 85, GLY } 34 \text {, ASP } \\
218 \text {, ASP } 32 \text {, GLY } 220 .\end{array}$ & 0 & 0 & $\begin{array}{l}\text { ILE } 123 \text {, ILE } 30 \text {, ASP } 86 \text {, SER } 35 \text {, } \\
\text { TYR } 84 \text {, GLY } 85 \text {, GLY } 34 \text {, ASP } \\
218 \text {, ASP } 32 \text {, GLY } 220 .\end{array}$ \\
\hline 3. & m-Cymene & -3.58 & $\begin{array}{l}\text { ASP 32, GLY 34, SER 35, ILE } \\
\text { 305, LEU 216, ASP 218, GLY } 220 . \\
\text { ILE 123, ASP 86, TYR } 84 .\end{array}$ & 0 & 0 & $\begin{array}{l}\text { ASP 32, GLY 34, SER 35, ILE } \\
\text { 305, LEU 216, ASP 218, GLY } 220 . \\
\text { ILE 123, ASP 86, TYR } 84 .\end{array}$ \\
\hline 4. & Davanol & -2.94 & $\begin{array}{l}\text { THR } 78 \text {, GLY 135, PHE } 80 \text {, LEU } \\
\text { 94, ALA 134, ALA 133, TYR 81, } \\
\text { PRO } 79 .\end{array}$ & 0 & 0 & $\begin{array}{l}\text { THR } 78 \text {, GLY 135, PHE 80, LEU } \\
\text { 94, ALA 134, ALA 133, TYR 81, } \\
\text { PRO } 79 .\end{array}$ \\
\hline 5. & Dillapiole & -3.91 & $\begin{array}{l}\text { GLY } 220 \text {, ASP } 86 \text {, TYR } 225 \text {, THR } \\
221 \text {, VAL } 12 \text {, SER 13, ILE } 30, \\
\text { ASP } 32 \text {, ILE } 123\end{array}$ & 1 & THR 222 & $\begin{array}{l}\text { GLY } 220 \text {, ASP } 86 \text {, TYR } 225 \text {, THR } \\
221 \text {, VAL } 12 \text {, SER 13, ILE } 30 \text {, } \\
\text { ASP } 32 \text {, ILE } 123\end{array}$ \\
\hline 6. & Foeniculin & -4.36 & $\begin{array}{l}\text { VAL } 12 \text {, GLY } 220 \text {, THR } 222 \text {, THR } \\
221 \text {, TYR } 225 \text {, GLY } 85 \text {, ILE } 305 \text {, } \\
\text { ASP } 86 \text {, ILE } 30 \text {, SER } 13\end{array}$ & 0 & 0 & $\begin{array}{l}\text { VAL } 12 \text {, GLY } 220 \text {, THR } 222 \text {, THR } \\
221 \text {, TYR } 225 \text {, GLY } 85 \text {, ILE } 305 \text {, } \\
\text { ASP } 86 \text {, ILE } 30 \text {, SER } 13\end{array}$ \\
\hline 7. & Ligustillide & -5.75 & $\begin{array}{l}\text { ILE } 305 \text {, THR 221, VAL 12, ILE } \\
\text { 30, SER 13, GLY 220, ASP } 86\end{array}$ & 3 & $\begin{array}{l}\text { ILE 223, TYR 225, } \\
\text { THR } 222\end{array}$ & $\begin{array}{l}\text { ILE } 305 \text {, THR 221, VAL 12, ILE } \\
\text { 30, SER 13, GLY 220, ASP } 86\end{array}$ \\
\hline 8. & $\begin{array}{l}\text { Methyl } \\
\text { Hexadecanoate }\end{array}$ & +0.92 & $\begin{array}{l}\text { LEU } 76, \text { THR } 78 \text {, PRO 79, PHE } \\
80, \text { TYR } 81 \text {, TYR } 81 \text {, ALA } 133 \text {, } \\
\text { GLY } 135\end{array}$ & 0 & 0 & $\begin{array}{l}\text { LEU } 76, \text { THR } 78 \text {, PRO 79, PHE } \\
\text { 80, TYR 81, TYR 81, ALA 133, } \\
\text { GLY } 135\end{array}$ \\
\hline 9. & o-Cymene & -3.62 & $\begin{array}{l}\text { GLY } 220 \text {, ASP } 86 \text {, THR } 221 \text {, ASP } \\
\text { 218, GLY 34, SER 35, ILE } 123 \text {, } \\
\text { TYR 84, ASP 32, ILE } 30\end{array}$ & 0 & 0 & $\begin{array}{l}\text { GLY } 220 \text {, ASP } 86, \text { THR } 221, \text { ASP } \\
218, \text { GLY } 34 \text {, SER } 35 \text {, ILE } 123 \text {, } \\
\text { TYR } 84 \text {, ASP } 32 \text {, ILE } 30\end{array}$ \\
\hline 10. & p-Cymene & -3.65 & $\begin{array}{l}\text { ASP } 86, \text { THR 221, ILE } 305 \text {, ASP } \\
218, \text { TYR 84, GLY 34, GLY 220, } \\
\text { ASP } 32 \text {, ILE 30, ILE } 123\end{array}$ & 0 & 0 & $\begin{array}{l}\text { ASP } 86, \text { THR } 221 \text {, ILE } 305, \text { ASP } \\
218, \text { TYR 84, GLY 34, GLY 220, } \\
\text { ASP } 32, \text { ILE } 30, \text { ILE } 123\end{array}$ \\
\hline 11. & Phellandrene & -3.97 & $\begin{array}{l}\text { ILE } 123, \text { GLY 220, ASP } 32, \text { TYR } \\
84, \text { THR } 221, \text { ASP } 218, \text { ASP } 86\end{array}$ & 0 & 0 & $\begin{array}{l}\text { ILE } 123, \text { GLY 220, ASP } 32 \text {, TYR } \\
84, \text { THR 221, ASP 218, ASP } 86\end{array}$ \\
\hline 12. & Tetradecanal & -3.17 & $\begin{array}{l}\text { THR 221, TYR 225, ASP 86, TYR } \\
\text { 84, ASP 32, ILE } 123 \text {, ILE 30, GLY } \\
\text { 220, SER 13, VAL } 12\end{array}$ & 1 & THR 222 & $\begin{array}{l}\text { THR 221, TYR 225, ASP 86, TYR } \\
\text { 84, ASP 32, ILE 123, ILE 30, GLY } \\
\text { 220, SER 13, VAL } 12\end{array}$ \\
\hline 13. & Thujanol & -4.14 & $\begin{array}{l}\text { ASP } 86, \text { TYR } 84 \text {, SER } 35 \text {, GLY } \\
85 \text {, GLY } 34 \text {, THR 221, ASP } 218 \text {, } \\
\text { ILE } 305 \text {, ILE } 30 \text {, ILE } 123 \text {, ASP } \\
32, \text { GLY } 220\end{array}$ & 1 & ASP 218 & $\begin{array}{l}\text { ASP } 86, \text { TYR } 84 \text {, SER } 35 \text {, GLY } \\
85 \text {, GLY } 34 \text {, THR 221, ASP } 218 \text {, } \\
\text { ILE } 305 \text {, ILE } 30 \text {, ILE } 123 \text {, ASP } \\
32, \text { GLY } 220\end{array}$ \\
\hline 14. & Thymol & -4.05 & $\begin{array}{l}\text { GLY } 220 \text {, ASP } 218 \text {, THR 221, } \\
\text { GLY } 85 \text {, ASP } 86 \text {, ILE } 305 \text {, GLY } \\
\text { 34, SER 35, TYR 84, ILE } 30 \text {, } \\
\text { ILE } 123\end{array}$ & 1 & ASP 32 & $\begin{array}{l}\text { GLY } 220, \text { ASP } 218, \text { THR } 221 \text {, } \\
\text { GLY } 85 \text {, ASP } 86 \text {, ILE } 305 \text {, GLY } \\
\text { 34, SER 35, TYR 84, ILE } 30, \\
\text { ILE } 123\end{array}$ \\
\hline 15. & Totarol & -4.87 & $\begin{array}{l}\text { VAL } 12 \text {, SER } 13 \text {, TYR } 84 \text {, ILE } \\
\text { 123, ILE 30, SER 35, ASP 86, } \\
\text { GLY 220, THR 221, THR } 222\end{array}$ & 1 & ASP 32 & $\begin{array}{l}\text { VAL } 12 \text {, SER } 13 \text {, TYR } 84 \text {, ILE } \\
\text { 123, ILE 30, SER 35, ASP } 86 \text {, } \\
\text { GLY 220, THR 221, THR } 222\end{array}$ \\
\hline
\end{tabular}




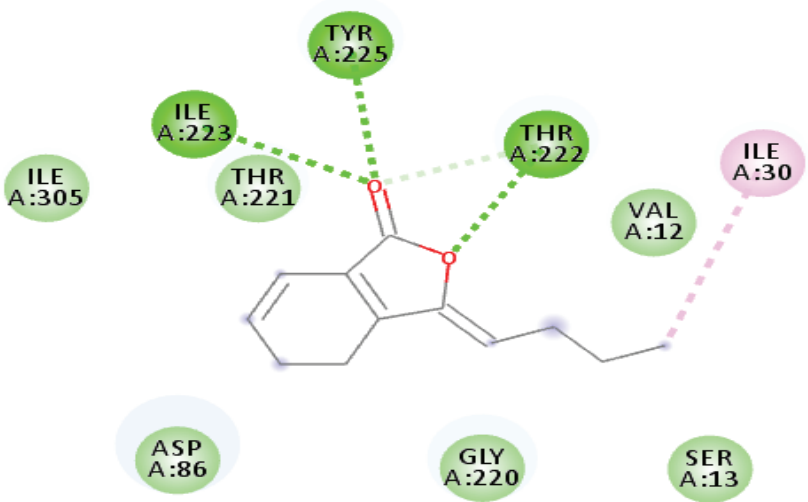

\section{Interactions}

van der Waals

Conventional Hydrogen Bond

Carbon Hydrogen Bond

Alkyl

Figure 2. Two-dimensional and three-dimensional residual interactions map of ligustilide against the active site of Candidapepsin-1.

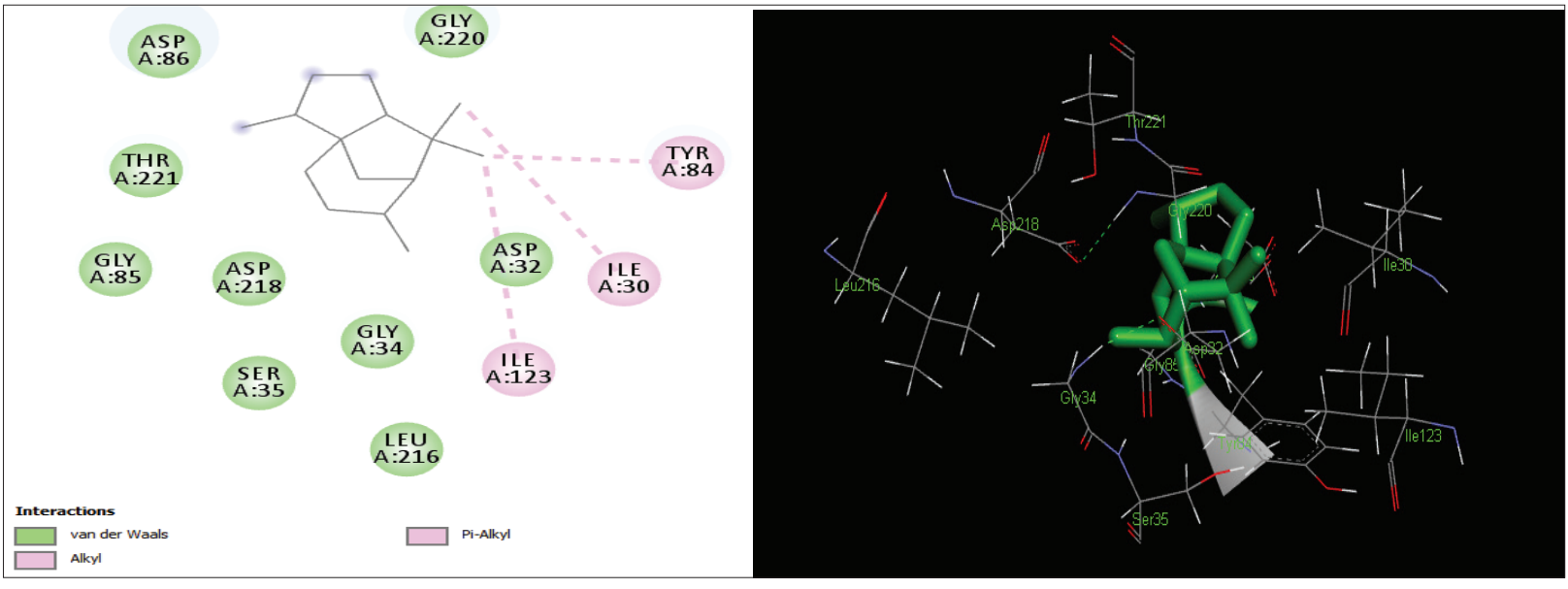

Figure 3. Two-dimensional and three-dimensional residual interactions map of cedrane against the active site of Candidapepsin-1.

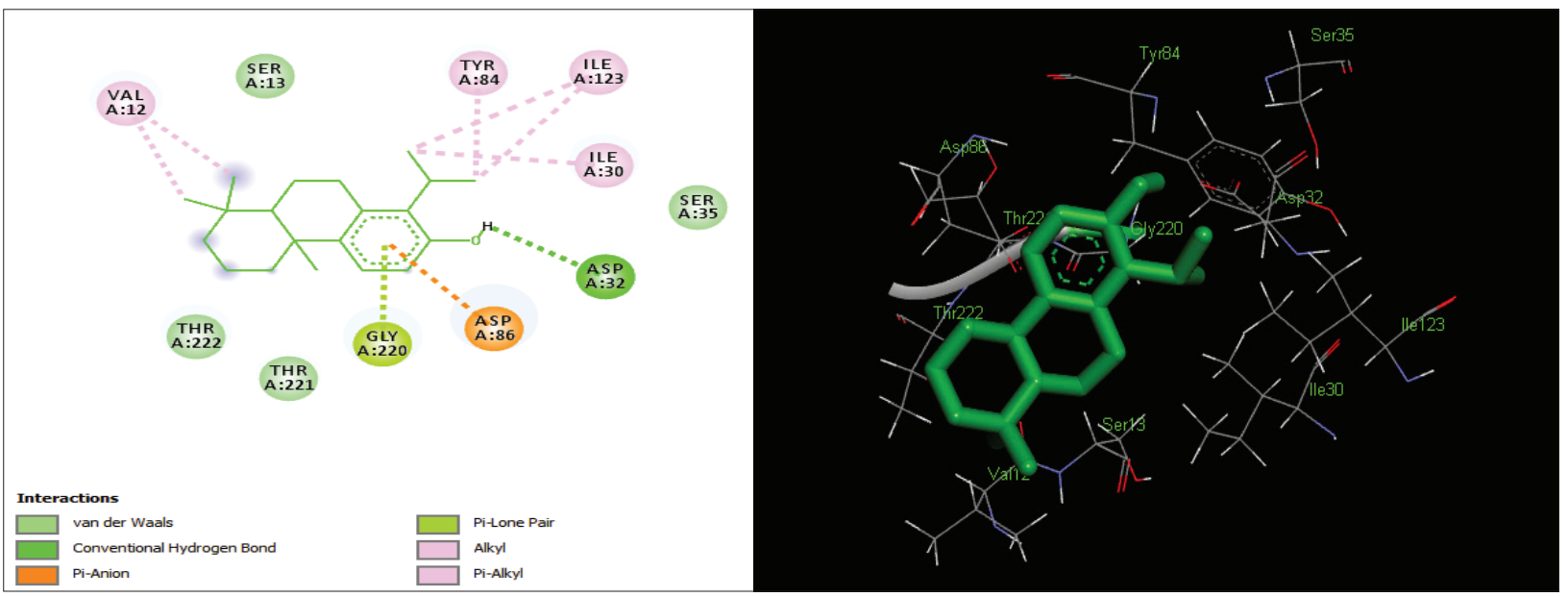

Figure 4. Two-dimensional and three-dimensional residual interactions map of totarol against the active site of Candidapepsin-1. 


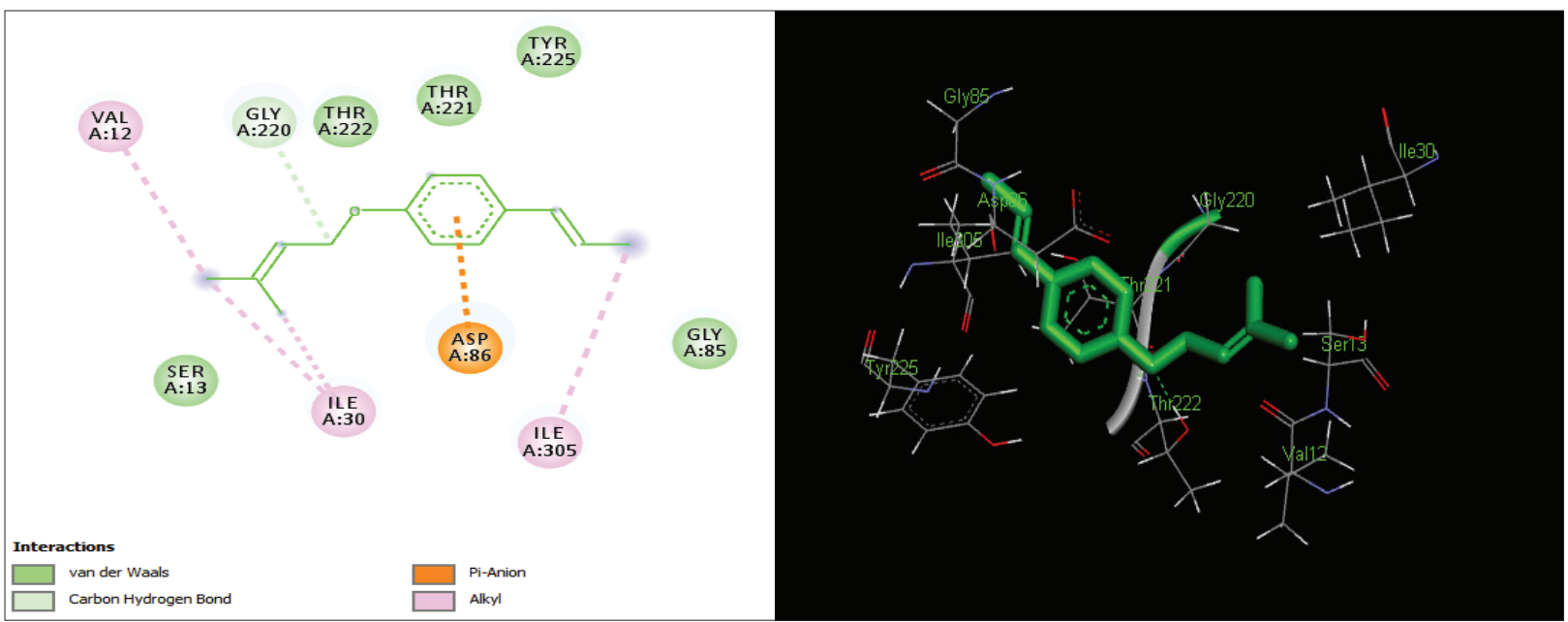

Figure 5. Two-dimensional and three-dimensional residual interactions map of foeniculin against the active site of Candidapepsin-1.

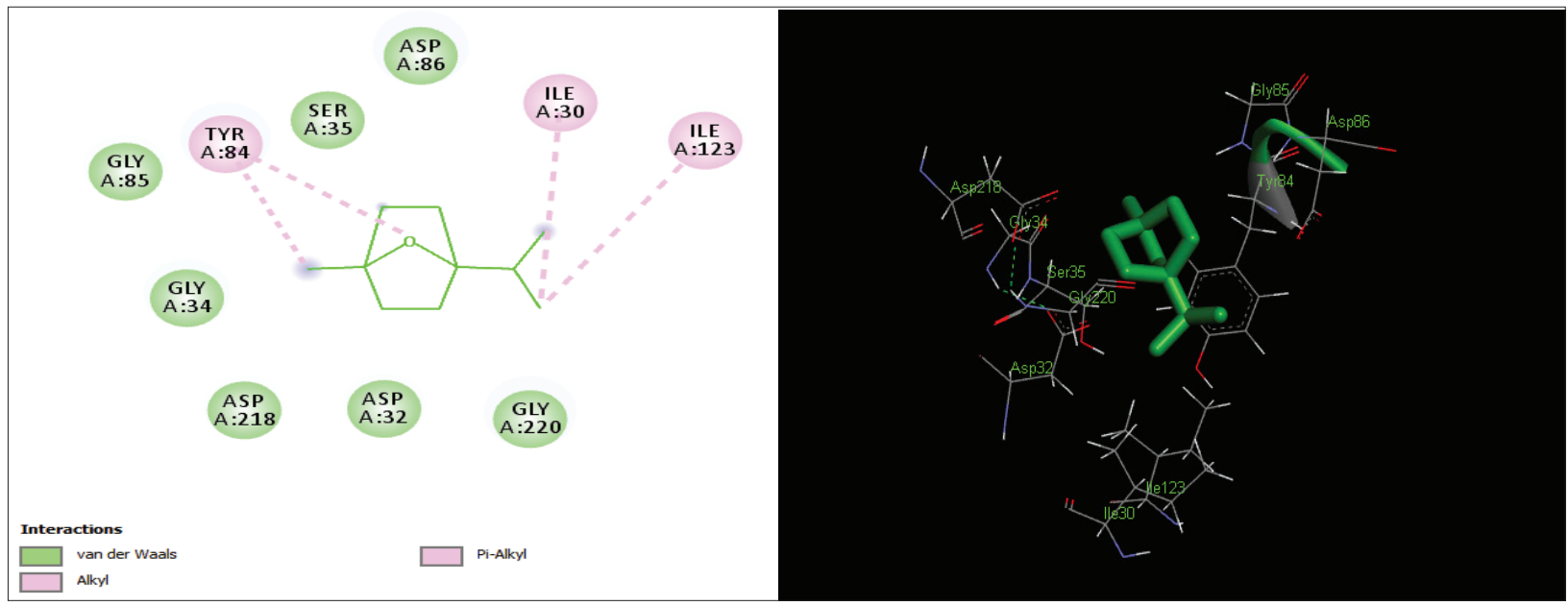

Figure 6. Two-dimensional and three-dimensional residual interactions map of cineole against the active site of Candidapepsin-1.

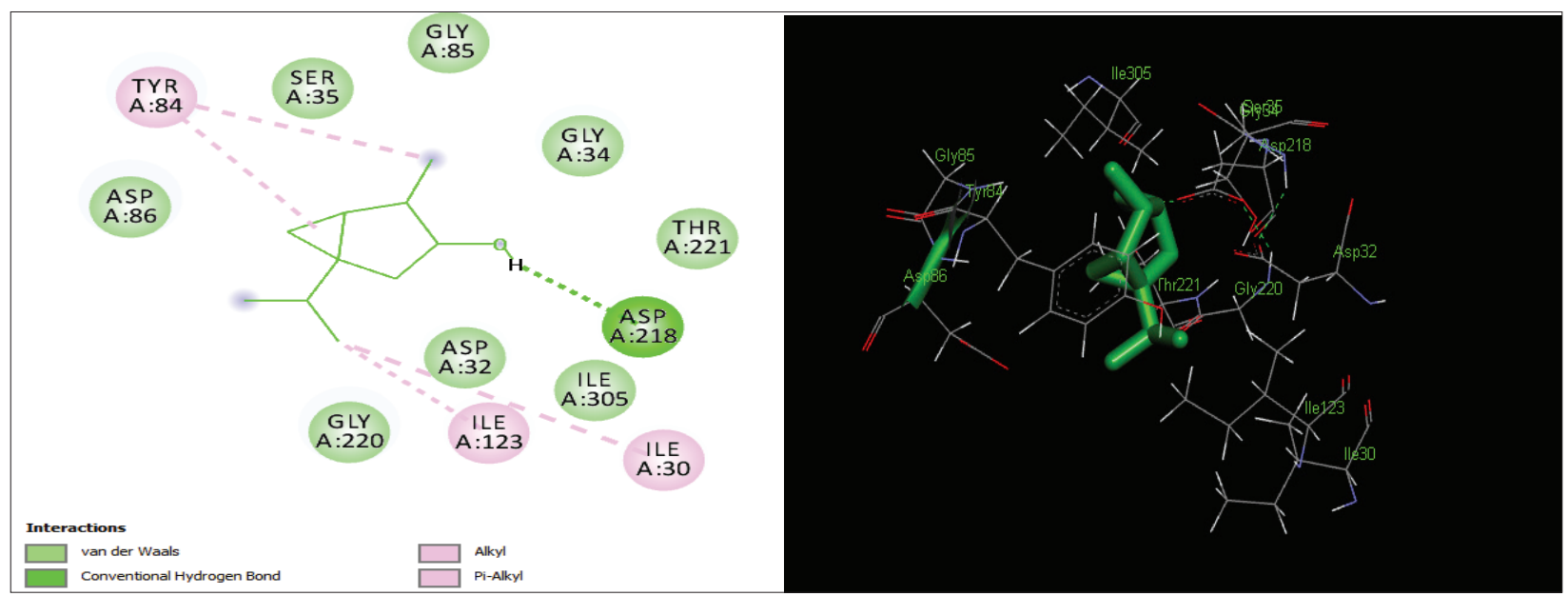

Figure 7. Two-dimensional and three-dimensional residual interactions map of thujanol against the active site of Candidapepsin-1. 


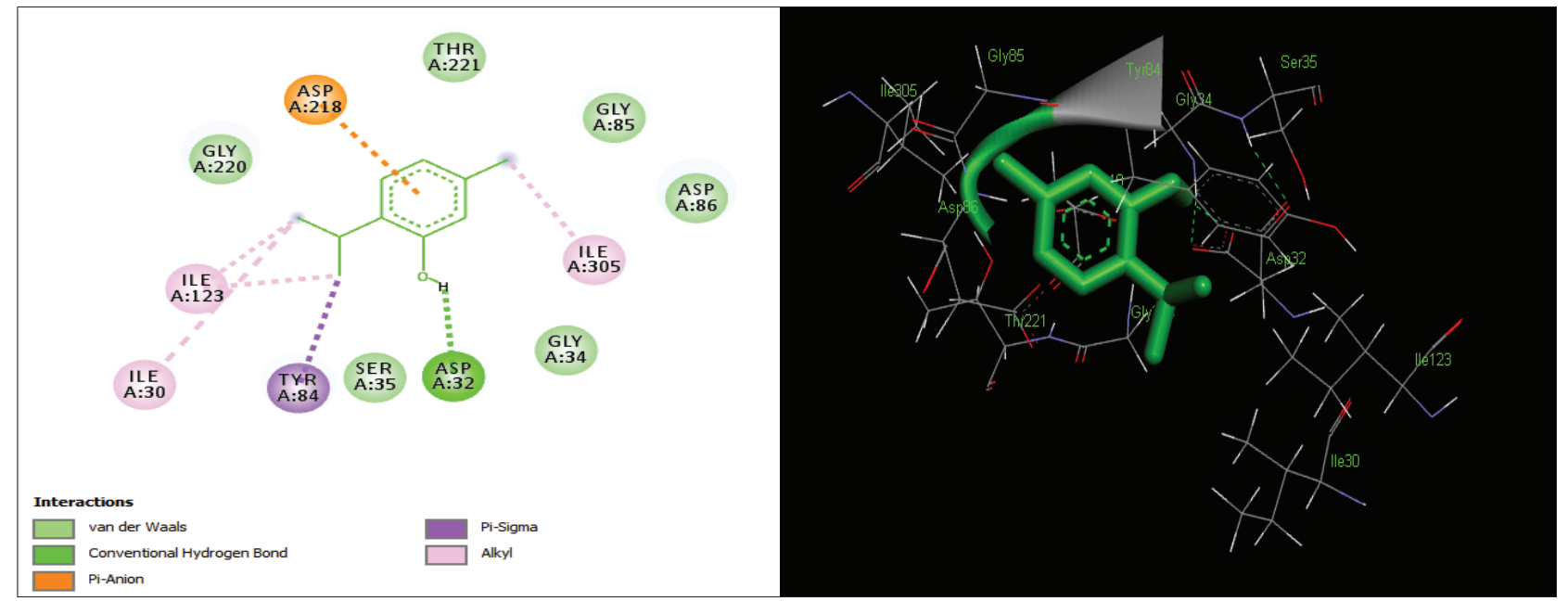

Figure 8. Two-dimensional and three-dimensional residual interactions map of thymol against the active site of Candidapepsin-1.

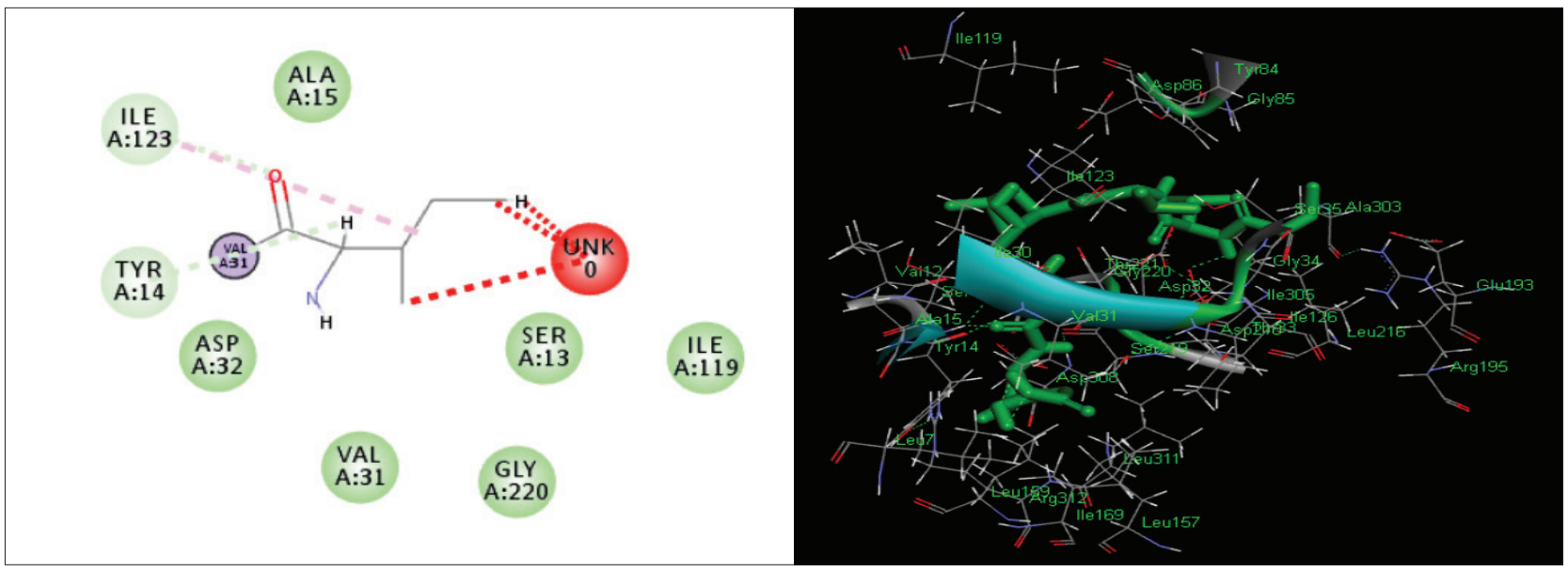

Figure 9. Two-dimensional and three-dimensional residual interactions map of Pepstatin A against the active site of Candidapepsin-1.

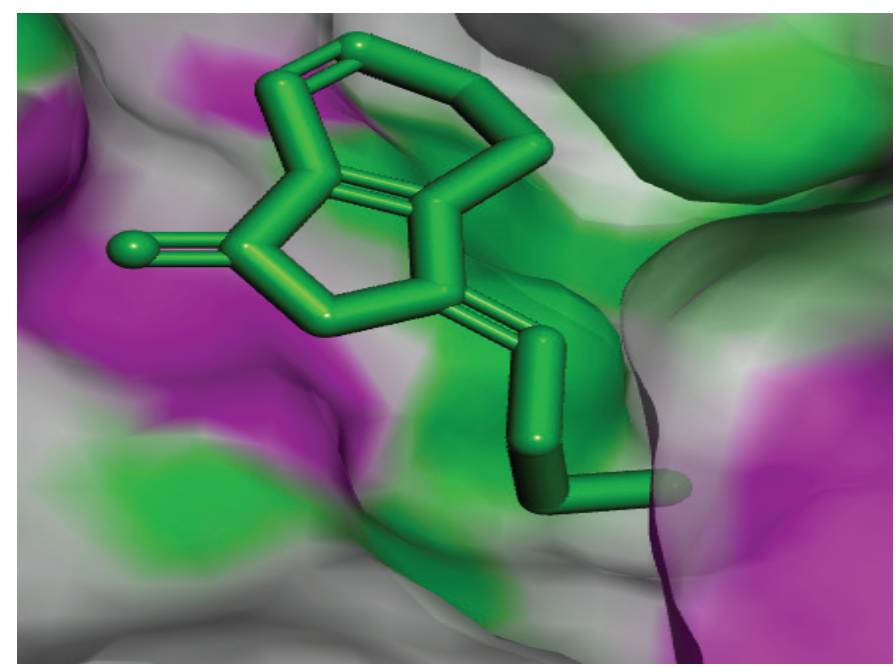

Figure 10. Docked conformation of ligustilide against the active site of Candidapepsin-1.

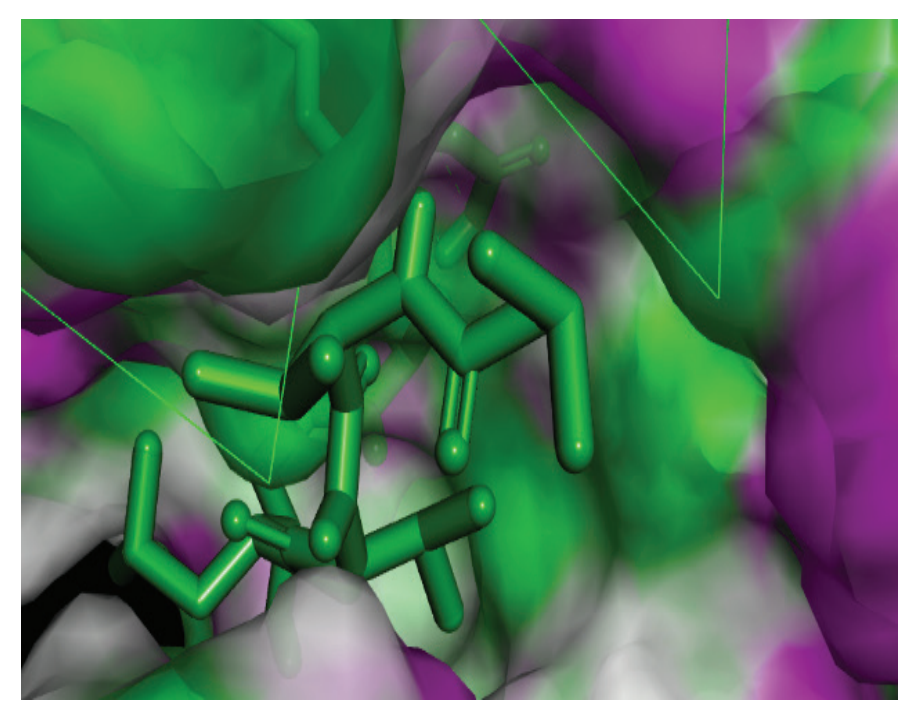

Figure 11. Docked conformation of Pepstatin A against the active site of Candidapepsin -1. 
Table 4. Absorption properties of various bioactive compounds.

\begin{tabular}{|c|c|c|c|c|c|c|c|c|}
\hline S. No & Compound & $\begin{array}{l}\text { Water solubility } \\
\text { (log mol/l) }\end{array}$ & $\begin{array}{c}\mathrm{CACO}_{2} \text { permeability } \\
\left(\mathrm{Log} \mathrm{Pabb} \text { in } 10^{-6} \mathrm{~cm} / \mathrm{Sec}\right)\end{array}$ & $\begin{array}{c}\text { GI absorption } \\
(\%)\end{array}$ & $\begin{array}{c}\text { Skin permeability } \\
\text { (Log Kp) }\end{array}$ & $\begin{array}{l}\text { P-glycoprotein } \\
\text { substrate }\end{array}$ & $\begin{array}{l}\text { P-glycoprotein } \\
\text { I inhibitor }\end{array}$ & $\begin{array}{l}\text { P-glycoprotein } \\
\text { II inhibitor }\end{array}$ \\
\hline 1 & Cedrane & -6.06 & 1.38 & 94.42 & -2.12 & No & No & No \\
\hline 2 & Cineole & -2.77 & 1.51 & 96.26 & -2.13 & Yes & No & No \\
\hline 3 & m-Cymene & -4.10 & 1.53 & 93.65 & -1.21 & No & No & No \\
\hline 4 & Davanol & -3.24 & 1.64 & 93.41 & -2.29 & No & No & No \\
\hline 5 & Dillapiole & -2.44 & 1.83 & 95.10 & -2.45 & No & No & No \\
\hline 6 & Foeniculin & -4.65 & 1.80 & 95.04 & -1.30 & No & No & No \\
\hline 7 & Ligustillide & -3.09 & 1.62 & 96.30 & -2.22 & No & No & No \\
\hline 8 & Methyl palmitate & -6.93 & 1.60 & 92.33 & -2.60 & No & No & No \\
\hline 9 & o-Cymene & -4.11 & 1.53 & 93.88 & -1.18 & No & No & No \\
\hline 10 & p-Cymene & -4.08 & 1.53 & 93.54 & -1.19 & No & No & No \\
\hline 11 & Phellandrene & -3.85 & 1.41 & 96.55 & -1.51 & No & No & No \\
\hline 12 & Tetradecanal & -6.49 & 1.48 & 93.02 & -2.07 & No & No & No \\
\hline 13 & Thujanol & -2.51 & 1.50 & 94.78 & -2.13 & No & No & No \\
\hline 14 & Thymol & -2.79 & 1.61 & 90.84 & -1.62 & No & No & No \\
\hline 15 & Totarol & -5.91 & 1.56 & 92.77 & -2.65 & No & No & Yes \\
\hline
\end{tabular}

Table 5. Distribution properties of various bioactive compounds.

\begin{tabular}{|c|c|c|c|c|c|}
\hline S. no & Compound & $\begin{array}{l}\text { VDss (human) } \\
\text { (Log L/kg) }\end{array}$ & $\begin{array}{l}\text { Fraction unbound (human) } \\
\text { (Fu) }\end{array}$ & $\begin{array}{c}\text { BBB permeability } \\
\text { (Log BB) }\end{array}$ & $\begin{array}{c}\text { CNS permeability } \\
\text { (Log PS) }\end{array}$ \\
\hline 1 & Cedrane & 0.67 & 0.10 & 0.84 & -1.44 \\
\hline 2 & Cineole & 0.36 & 0.51 & 0.67 & -2.55 \\
\hline 3 & m-Cymene & 0.72 & 0.15 & 0.47 & -1.39 \\
\hline 4 & Davanol & 0.23 & 0.40 & 0.55 & -2.84 \\
\hline 5 & Dillapiole & 0.03 & 0.20 & -0.22 & -2.24 \\
\hline 6 & Foeniculin & 0.68 & 0.11 & 0.62 & -1.70 \\
\hline 7 & Ligustillide & 0.30 & 0.42 & 0.56 & -2.45 \\
\hline 8 & Methyl palmitate & 0.23 & 0.07 & 0.75 & -1.68 \\
\hline 9 & o-Cymene & 0.74 & 0.16 & 0.48 & -1.40 \\
\hline 10 & p-Cymene & 0.70 & 0.16 & 0.48 & -1.39 \\
\hline 11 & Phellandrene & 0.41 & 0.43 & 0.76 & -2.05 \\
\hline 12 & Tetradecanal & 0.48 & 0.15 & 0.78 & -1.67 \\
\hline 13 & Thujanol & 0.35 & 0.47 & 0.66 & -2.24 \\
\hline 14 & Thymol & 0.51 & 0.20 & 0.41 & -1.66 \\
\hline 15 & Totarol & 1.16 & 0 & 0.55 & -1.35 \\
\hline
\end{tabular}

dimensional interactions of the ligustilide with the enzyme are depicted in Figure 2. Cedrane with the binding energy of -5.20 $\mathrm{kcal} / \mathrm{mol}$ occupies the next spot in the ranking Figure 3 . Totarol $(-4.87 \mathrm{kcal} / \mathrm{mol})$, foeniculin $(-4.36 \mathrm{kcal} / \mathrm{mol})$, cineole $(-4.20$ $\mathrm{kcal} / \mathrm{mol})$, thujanol $(-4.14 \mathrm{kcal} / \mathrm{mol})$, and thymol $(-4.05 \mathrm{kcal} / \mathrm{mol})$ follow up the order. The binding energies of bioactive compounds docked were compared with the binding energy of the reference ligand (Pepstatin A) (Fig. 9) against the enzyme with the same grid parameters. The binding energy of reference inhibitor ligand was found to be $+2.77 \mathrm{kcal} / \mathrm{mol}$, which is lower when compared to the binding energies of bioactive compounds from T. ammi (Fig. 11). The binding of bioactive compounds inhibits the activity of enzyme resulting in the neutralization the enzymes virulence (Hube et al., 1997). Ligustilide isolated from essential oil of Umbelliferae family has immense antifungal properties against several species of fungi, thus restricting the fungal growth and proliferations (Lee et al., 2008). Essential oils from T. ammi at different temperatures and pressures through minimum inhibitory concentration (MIC) studies against a variety of Candida species were studied by Rath and Mohapatra (2015). The MIC values for essential oil from $T$. ammi was $31.25 \mu \mathrm{l} / \mathrm{ml}$ for C. albicans, and C. tropicalis, $62.50 \mu \mathrm{l} /$ $\mathrm{ml}$ for Candida glabratra, and $125 \mu \mathrm{l} / \mathrm{ml}$ for Candida parapsilosis, respectively (Rath and Mohapatra, 2015). This proves that the essential bioactive compounds from the oil has antifungal potential and can be used in therapeutic applications. Also, upon increasing the temperature and pressure had an augmented therapeutic inhibition potential of the essential oil against Candida infection (Pattnaik et al., 1995). Fungal hyphae are an important measure for the fungal growth and virulence. The development of the hyphae is inhibited by thymol, hence disturbing the cell membrane 
Table 6. Metabolism properties of various bioactive compounds.

\begin{tabular}{|c|c|c|c|c|c|c|c|c|}
\hline S. no & Compound & $\begin{array}{l}\text { CYP2D6 } \\
\text { substrate }\end{array}$ & $\begin{array}{l}\text { CYP3A4 } \\
\text { substrate }\end{array}$ & $\begin{array}{l}\text { CYP1A2 } \\
\text { inhibitor }\end{array}$ & $\begin{array}{l}\text { CYP2C19 } \\
\text { inhibitor }\end{array}$ & $\begin{array}{l}\text { CYP2C9 } \\
\text { inhibitor }\end{array}$ & $\begin{array}{l}\text { CYP2D6 } \\
\text { inhibitor }\end{array}$ & $\begin{array}{l}\text { CYP3A4 } \\
\text { inhibitor }\end{array}$ \\
\hline 1 & Cedrane & No & Yes & Yes & No & No & No & No \\
\hline 2 & Cineole & No & No & No & No & No & No & No \\
\hline 3 & m-Cymene & No & No & Yes & No & No & No & No \\
\hline 4 & Davanol & No & No & No & No & No & No & No \\
\hline 5 & Dillapiole & No & Yes & Yes & No & No & No & No \\
\hline 6 & Foeniculin & No & No & Yes & No & No & No & No \\
\hline 7 & Ligustillide & No & No & No & No & No & No & No \\
\hline 8 & Methyl palmitate & No & Yes & Yes & No & No & No & No \\
\hline 9 & o-Cymene & No & No & Yes & No & No & No & No \\
\hline 10 & p-Cymene & No & No & Yes & No & No & No & No \\
\hline 11 & Phellandrene & No & No & No & No & No & No & No \\
\hline 12 & Tetradecanal & No & Yes & No & No & No & No & No \\
\hline 13 & Thujanol & No & No & No & No & No & No & No \\
\hline 14 & Thymol & No & No & Yes & No & No & No & No \\
\hline 15 & Totarol & No & Yes & Yes & No & No & No & No \\
\hline
\end{tabular}

Table 7. Excretion and toxicity properties of various bioactive compounds.

\begin{tabular}{|c|c|c|c|c|c|c|c|c|c|}
\hline $\begin{array}{l}\text { S. } \\
\text { no }\end{array}$ & Compound & $\begin{array}{l}\text { AMES } \\
\text { toxicity }\end{array}$ & $\begin{array}{c}\text { Max. tolerated } \\
\text { dose (human) } \\
\text { (Log mg/kg/day) }\end{array}$ & $\begin{array}{c}\text { hERG I } \\
\text { inhibitor }\end{array}$ & $\begin{array}{l}\text { hERG II } \\
\text { inhibitor }\end{array}$ & $\begin{array}{c}\text { Oral Rat Acute } \\
\text { Toxicity (LD50) } \\
\quad(\mathrm{mol} / \mathrm{kg})\end{array}$ & $\begin{array}{c}\text { Oral Rat Chronic } \\
\text { Toxicity (LOAEL) } \\
\quad(\mathrm{Log} \mathrm{mg} / \mathrm{kg})\end{array}$ & Hepatotoxicity & $\begin{array}{c}\text { Skin } \\
\text { Sensitisation }\end{array}$ \\
\hline 1 & Cedrane & No & -0.43 & No & No & 1.62 & 1.33 & No & No \\
\hline 2 & Cineole & No & 0.59 & No & No & 1.85 & 2.07 & No & Yes \\
\hline 3 & m-Cymene & No & 0.89 & No & No & 1.83 & 2.34 & No & Yes \\
\hline 4 & Davanol & No & 0.39 & No & No & 1.85 & 2.02 & No & Yes \\
\hline 5 & Dillapiole & No & 0.73 & No & No & 0.25 & 1.85 & No & No \\
\hline 6 & Foeniculin & No & 0.86 & No & No & 1.78 & 1.31 & No & Yes \\
\hline 7 & Ligustillide & No & 0.41 & No & No & 1.86 & 2.14 & No & Yes \\
\hline 8 & Methyl palmitate & No & 0.18 & No & No & 1.64 & 2.99 & No & Yes \\
\hline 9 & o-Cymene & No & 0.88 & No & No & 1.79 & 2.32 & No & Yes \\
\hline 10 & p-Cymene & No & 0.90 & No & No & 1.83 & 2.33 & No & Yes \\
\hline 11 & Phellandrene & No & 0.75 & No & No & 1.74 & 2.33 & No & No \\
\hline 12 & Tetradecanal & No & 0.16 & No & No & 1.50 & 1.22 & No & Yes \\
\hline 13 & Thujanol & No & 0.64 & No & No & 1.70 & 1.93 & No & Yes \\
\hline 14 & Thymol & No & 1.00 & No & No & 2.07 & 2.21 & Yes & Yes \\
\hline 15 & Totarol & No & -0.21 & No & Yes & 2.60 & 1.16 & No & Yes \\
\hline
\end{tabular}

thereby affecting the enzymes responsible for cell wall synthesis (Braga et al., 2007). Figures 2-10 list the two-dimensional and three-dimensional interactions of bioactive compounds with low binding energies against Candidapepsin-1. ADMET profiles of the compounds were depicted in Tables 4-7. All the compounds have high rates of gastrointestinal absorption (Table 4). From Table 5, it is clear that none of the drug penetrates the blood-brain barrier since the $\log \mathrm{BB}$ value of all the compounds is less than three. For a drug to cross the blood-brain barrier, the $\log B \mathrm{~B}$ value must be greater than three (Muehlbacher et al., 2011).

\section{CONCLUSION}

Trachyaspermum ammi is traditionally used in ayurvedic medicine due to its anti-inflammatory, antifungal, antibacterial, anticancer, and antiarthritic potential. The current study revealed the inhibition potential of bioactive compounds from essential oil of $T$. ammi against the virulent enzyme Candidapepsin-1 of C. albicans. The bioactive compound ligustilide has the lowest binding energy of $-5.75 \mathrm{kcal} / \mathrm{mol}$. This proves the antifungal activity of the T. ammi against the Candida biofilm formation, there by inhibiting the virulence of the enzyme. The inhibition of the enzyme leads to novel discovery of plant-based therapeutic products. Computational molecular docking could be used as an effective supporting tool for the drug development process. Computational simulations also provide us with comprehensive results with high accuracy. Hence, their presence is necessary toward the development of drug discovery and development sector. 


\section{ACKNOWLEDGMENTS}

The authors would like to thank Vels Institute of Science, Technology and Advanced Studies (VISTAS) management to carry out this research work.

\section{FUNDING}

Nil.

\section{CONFLICTS OF INTEREST}

Authors declare that there are no conflicts of interest.

\section{REFERENCES}

Ahsan SK, Shah AH, Tanira MO, Ahmad MS, Tariq M, Ageel AM. Studies on some herbal drugs used against kidney stones in Saudi folk medicine, Fitoterapia, 1990; 61:435-8.

Almagro JC, Beavers MP, Hernandez-Guzman F, Maier J, Shaulsky J, Butenhof K, Labute P, Thorsteinson N, Kelly K, Teplyakov A, Luo J. Antibody modeling assessment. Proteins Struct Funct Bioinf, 2011; 79:3050-66.

Aoki W, Kitahara N, Miura N, Morisaka H, Yamamoto Y, Kuroda $\mathrm{K}$, Ueda M. Comprehensive characterization of secreted aspartic proteases encoded by a virulence gene family in Candida albicans. J Biochem, 2011; 150:431-8.

Bairwa R, Sodha RS, Rajawat BS. Trachyspermum ammi. Pharmacogn Rev, 2012; 6:56-60.

Benet LZ, Hosey CM, Ursu O, Oprea TI. BDDCS, the rule of 5 and drugability. Adv Drug Deliv Rev, 2016; 101:89-98.

Borelli C, Ruge E, Lee JH, Schaller M, Vogelsang A, Monod M, Korting HC, Huber R, Maskos K. X-ray structures of Sap1 and Sap5: structural comparison of the secreted aspartic proteinases from Candida albicans. Proteins Struct Funct Bioinf, 2008; 72:1308-19.

Braga PC, Alfieri M, Culici M, Dal Sasso M. Inhibitory activity of thymol against the formation and viability of Candida albicans hyphae. Mycoses, 2007; 50:502-6.

Correia A, Lermann U, Teixeira L, Cerca F, Botelho S, da Costa RM, Sampaio P, Gärtner F, Morschhäuser J, Vilanova M, Pais C. Limited role of secreted aspartyl proteinases Sap1 to Sap6 in Candida albicans virulence and host immune response in murine hematogenously disseminated candidiasis. Infect Immun, 2010; 78:4839-49.

Dhaiwal K, Chahal KK, Kataria D, Kumar A. Gas chromatography-mass spectrometry analysis and in vitro antioxidant potential of ajwain seed (Trachyspermum ammi L.) essential oil and its extracts. J Food Biochem 2017; 41:e12364.

Garg SN, Kumar S. A new glucoside from Trachyspermum ammi. Fitoterapia, 1998; 69:511-2.

Gilani AH, Jabeen Q, Ghayur MN, Janbaz KH, Akhtar MS. Studies on the antihypertensive, antispasmodic, bronchodilator and hepatoprotective activities of the Carum copticum seed extract. J Ethnopharmacol, 2005; 98:127-35.

Hube B, Sanglard D, Odds FC, Hess D, Monod M, Schäfer WI, Brown AJ, Gow NA. Disruption of each of the secreted aspartyl proteinase genes SAP1, SAP2, and SAP3 of Candida albicans attenuates virulence. Infect Immun, 1997; 65:3529-38.

Ishikawa T, Sega Y, Kitajima J. Water-soluble constituents of ajowan. Chem Pharm Bull 2001; 49:840-4.

Ishwar S, Singh VP. Antifungal properties of aqueous and organic solution extracts of seed plants against Aspergillus flavus and $A$. niger. Phytomorphology, 2000; 50:151-7.

Javed S, Shahid AA, Haider MS, Umeera A, Ahmad R, Mushtaq S. Nutritional, phytochemical potential and pharmacological evaluation of Nigella sativa (Kalonji) and Trachyspermum ammi (Ajwain). J Med Plants Res, 2012; 6:768-75.

Joshi SG. Medicinal plants. Oxford and IBH publishing, New Delhi, India, 2000.
Kaur GJ, Arora DS. Antibacterial and phytochemical screening of Anethum graveolens, Foeniculum vulgare and Trachyspermum ammi. BMC Complement Altern Med, 2009; 9:30.

Kaur H. Estrogenic activity of some herbal galactogogue constituents. Indian J Anim Nutr, 1998; 15:232-4.

Khan R, Zakir M, Afaq SH, Latif A, Khan AU. Activity of solvent extracts of Prosopis spicigera, 7 Zingiber officinale and Trachyspermum ammi against multidrug resistant bacterial and fungal strains. J Infect Dev Countr, 2010; 4:292-300.

Kortemme T, Morozov AV, Baker D. An orientation-dependent hydrogen bonding potential improves prediction of specificity and structure for proteins and protein-protein complexes. J Mol Biol, 2003; 326:1239-59.

Korting HC, Patzak U, Schaller M, Maibach HI. A model of human cutaneous candidosis based on reconstructed human epidermis for the light and electron microscopic study of pathogenesis and treatment. J Infect, 1998; 36:259-67.

Kramer C, Ting A, Zheng H, Hert J, Schindler T, Stahl M, Robb G, Crawford JJ, Blaney J, Montague S, Leach AG. Learning medicinal chemistry absorption, distribution, metabolism, excretion, and toxicity (ADMET) rules from cross-company matched molecular pairs analysis (MMPA) miniperspective. J Med Chem, 2017; 61:3277-92.

Kumari KS, Prameela M. Effect of incorporating Carum copticum seeds in a high fat diet for albino rats. Med Sci Res, 1992; 20:219-20.

Lee JY, Chung EY, Sim Y, Shin S. Antifungal effects of ligustilide and butylidene phthalide and its synergism with antibiotics. Planta Med, 2008; 74:PA100.

Lipinski CA, Lombardo F, Dominy BW, Feeney PJ. Experimental and computational approaches to estimate solubility and permeability in drug discovery and development settings. Adv Drug Delivery Rev, 2012; 64:4-17.

Luu TT, Malcolm N, Nadassy K. Pharmacophore modeling methods in focused library selection-applications in the context of a new classification scheme. Comb Chem High Throughput Screen, 2011; 14:488-99.

Mathew N, Misra-Bhattacharya S, Perumal V, Muthuswamy K. Antifilarial lead molecules isolated from Trachyspermum ammi. Molecules, 2008; 13:2156-68.

Meenambiga SS, Rajagopal K, Durga R. In silico docking studies on the components of inonotus sp., a medicinal mushroom against cyclooxygenase-2 enzyme. Asian J Pharm Clin Res, 2015; 8:142-5.

Meenambiga SS, Venkataraghavan R, Biswal RA. In silico analysis of plant phytochemicals against secreted aspartic proteinase enzyme of Candida albicans. J Appl Pharm Sci, 2018; 8:140-50.

Naganathan S, Pazhamalai V, Natarajan A, Munusami H, Kothandaraman G. In silico anticancer analysis of bioactive compounds in Vitex altissima 1 and Vitex leucoxylon 1. J Chem Pharm Sci, 2016; 9:219-25.

Muehlbacher M, Spitzer GM, Liedl KR, Kornhuber J. Qualitative prediction of blood-brain barrier permeability on a large and refined dataset. J Comput Aided Mol Des, 2011; 25:1095-106.

Naglik JR, Challacombe SJ, Hube B. Candida albicans secreted aspartyl proteinases in virulence and pathogenesis. Microbiol Mol Biol Rev, 2003; 67:400-28.

Pattnaik S, Subramanyam VR, Rath CC. Effect of essential oils on the viability and morphology of Escherichia coli (SP-11). Microbios, 1995; 84:195-9.

Pruthi JS. Spices and condiments. 5th edition, National Book Organisation Publishers and Distributors, New Delhi, India, 1998.

Rath CC, Mohapatra S. Susceptibility characterisation of Candida spp. to four essential oils. Indian J Med Microbiol, 2015; 33:93-6.

Saeidnia S, Gohari AR, Hadjiakhoondi A, Afrapoli FM, Shafiee A. Cytotoxicity and chemical constituens of the volatile oil of golpar (Heracleum persicum desf. Ex Fischer). Biosci Res, 2005; 2:107-10.

Sanglard D, Hube B, Monod M, Odds FC, Gow NA. A triple deletion of the secreted aspartyl proteinase genes SAP4, SAP5, and SAP6 of Candida albicans causes attenuated virulence. Infect Immun, 1997; 65:3539-46. 
Sasikala RP, Meena KS. Molecular docking studies and admet properties of compounds from Physalis minima L. leaves root and fruit. Innov J Life Sci 2016; 4:21-5.

Schaller M, Januschke E, Schackert C, Woerle B, Korting HC. Different isoforms of secreted aspartyl proteinases (Sap) are expressed by Candida albicans during oral and cutaneous candidosis in vivo. J Med Microbiol, 2001; 50:743-7.

Smolenski G, Sullivan PA, Cutfield SM, Cutfield JF. Analysis of secreted aspartic proteinases from Candida albicans: purification and characterization of individual Sap1, Sap2 and Sap3 isoenzymes. Microbiology, 1997; 143:349-56.

Staib P, Kretschmar M, Nichterlein T, Hof H, Morschhäuser J. Differential activation of a Candida albicans virulence gene family during infection. Proc Natl Acad Sci USA, 2000; 97:6102-7.

Sutter J, Li J, Maynard A, Goupil A, Luu T, Nadassy K. New features that improve the pharmacophore tools from Accelrys. Curr Comput Aided Drug Des, 2011; 7:173-80.
Velazhahan R, Vijayanandraj S, Vijayasamundeeswari A, Paranidharan V, Samiyappan R, Iwamoto T, Friebe B, Muthukrishnan S. Detoxification of aflatoxins by seed extracts of the medicinal plant, Trachyspermum ammi (L.) Sprague ex Turrill-structural analysis and biological toxicity of degradation product of aflatoxin G1. Food Control, $2010 ; 21: 719-25$

\section{How to cite this article:}

Abhishek BR., Venkataraghavan R., Pazhamalai V, Ivo RS. Molecular docking of various bioactive compounds from essential oil of Trachyaspermum ammi against the fungal enzyme Candidapepsin-1. J Appl Pharm Sci, 2019; 9(05):021-032. 